C. Price, Y. Yair, A. Mugnai, K. Lagouvardos, M.C. Llasat, S.

Michaelides, U. Dayan, S. Dietrich, E. Galanti, L. Garrote, N. Harats, D. Katsanos, M. Kohn, V. Kotroni, M. Llasat-Botija, B. Lynn, L. Mediero, E. Morin, K. Nicolaides, S. Rozalis, K. Savvidou, B. Ziv, Environmental Science \& Policy, Vol. 14, Issue 7, 2011, pp. 898-911, DOI: 10.1016/j.envsci.2011.03.004

\title{
The FLASH Project: \\ Using lightning data to better understand and predict flash floods
}

C. Price, Y. Yair ${ }^{2}$, A. Mugnai ${ }^{3}$, K. Lagouvardos ${ }^{4}$, M. C. Llasat ${ }^{5}$, S. Michaelides ${ }^{6}$, U. Dayan $^{7}$, S. Dietrich ${ }^{3}$, E. Galanti', L. Garrote ${ }^{8}$, N. Harats' , D. Katsanos ${ }^{4}$, M. Kohn', V.

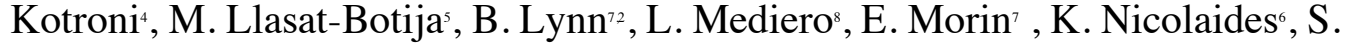
Rozalis', K. Savvidou', B. Ziv²

' Tel Aviv University, Tel Aviv, Israel

2 The Open University of Israel, Ra'anana, Israel

National Research Council, ISAC, Rome, Italy

${ }^{4}$ National Observatory of Athens, Athens, Greece

'University of Barcelona, Barcelona, Spain

${ }^{6}$ Cyprus Meteorological Service, Nicosia, Cyprus

Hebrew University of Jerusalem, Israel

${ }^{8}$ Technical University of Madrid, Spain

Paper submitted to Special Edition of

\section{Environmental Science \& Policy \\ "Climate Change and Water"}

Guest Eds. - Ph. Quevauviller, D. Peter and E. Lipiatou

February 2011 


\begin{abstract}
The FLASH project was implemented from 2006 to 2010 under the EU FP6 framework. The project focused on using lightning observations to better understand and predict convective storms that result in flash floods. As part of the project 23 case studies of flash floods in the Mediterranean region were examined. For the analysis of these storms lightning data from the ZEUS network were used together with satellite derived rainfall estimates in order to understand the storm development and electrification. In addition, these case studies were simulated using mesoscale meteorological models to better understand the meteorological and synoptic conditions leading up to these intense storms. As part of this project tools for short term predictions (nowcasts) of intense convection across the Mediterranean and Europe, and long term forecasts (a few days) of the likelihood of intense convection were developed. The project also focused on educational outreach through our website http://flashproject.org supplying real time lightning observations, real time experimental nowcasts, forecasts and educational materials. While flash floods and intense thunderstorms cannot be prevented as the climate changes, long-range regional lightning networks can supply valuable data, in real time, for warning endusers and stakeholders of imminent intense rainfall and possible flash floods.
\end{abstract}

\title{
1. Introduction
}

Thunderstorms can be very destructive as a result of intense rainfall that occurs over short periods of time, often resulting in flash floods. While many developed countries have weather radar networks to track storms and precipitation, the majority of the world is not covered by radar observations. In addition, radar coverage is usually sparse and inadequate in mountainous regions - such as most coastal regions of the Mediterranean basin that are prone to flash floods.

Since thunderstorms usually develop, mature and dissipate within $1-2 \mathrm{~h}$, there is a need to use data having high temporal resolution to develop methodologies to monitor intense thunderstorms continuously, especially in regions not covered by radar networks. Unlike radar observations of thunderstorms, lightning observations can be carried out from thousands of kilometers away due to the propagation of low frequency electromagnetic waves emitted from lightning discharges (Volland, 1995). 
Lightning observations provide a possibility of monitoring regional thunderstorm activity continuously in remote regions of the Mediterranean and Europe (Defer et al., 2005). Lightning activity also defines the convective core of thunderstorms where rainfall is normally the heaviest.

There is also evidence that flash floods, or intense rainfall events, may be increasing due to climate change (Intergovernmental Panel on Climate Change, 2007). These changes, together with the increasing world population, have resulted in huge increases in the damages and insured losses from flash floods around the world. Flash floods are one of the costliest natural hazards on a global scale. A recent report of the European Environmental Agency (http://www.eea.europa.eu/highlights/naturalhazards-and-technological-acci-dents) shows that flooding and storms were the most costly hazards in Europe in the period 1998-2009, with overall losses about EUR 52 billion for floods. At the global scale, reports from the UN International Strategy for Disaster Reduction (ISDR) show that floods are the disaster with the largest occurrence (http://www.unisdr.org/).

The FLASH project was focused on using lightning data in the study of intense convection that often leads to flash floods. Due to the nature of lightning observations, this allowed us to focus on large regions across the Mediterranean and Europe. The consortium included six partners from five countries (Israel, Italy, Greece, Spain and Cyprus) (Fig. 1).

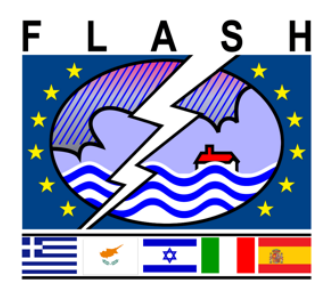

Fig. 1 - Logo of FLASH project

The FLASH project contained eight work packages (WP) dealing with three time frames (past, present and future) (Fig. 2). WP1 dealt with the past historic flash floods in the Mediterranean. Twenty three events were selected for detailed study. Their selection was based on the data availability and their societal impact. WP2-5 dealt 
with the present time frame, i.e. basic research on lightning observations, satellite rainfall estimations, numerical modeling of thunderstorms, and hydrology modeling. The future dimension was covered in WP6 and WP7 related to short and long term forecasting of intense convection that may lead to flash floods. Finally, WP8 dealt with the societal impacts of flash floods, and educational outreach to educate the public about thunderstorms, flash floods, and ways to reduce the public risk to thunderstorms and flash floods.

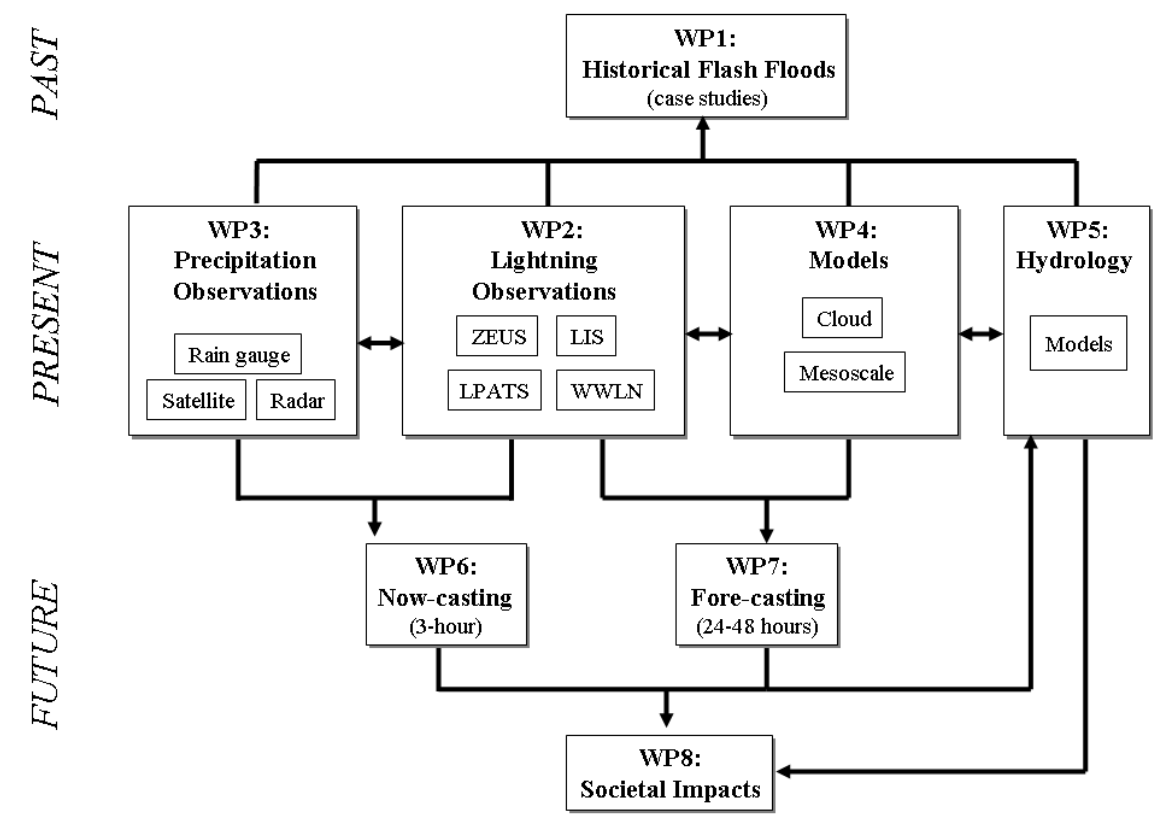

Fig. 2 - The work package structure of the FLASH project.

\section{Historical case studies}

As part of the FLASH project 23 case studies of heavy rainfall across the Mediterranean were chosen, for further intensive study. The criteria for selection were based on maximum data availability, especially lightning and satellite data. $66 \%$ of the cases produced flash floods, in which case hydrological and radar data were also recorded. Among the case studies we had both local and very isolated convective events, while also more extended precipitation with an important stratiform rainfall contribution, providing a suitable sample to test the models and forecasting capabilities developed in the project. In Fig. 3 the locations of the selected events are shown, spanning from Spain to Israel. The details of each case study are listed in Table 1. 


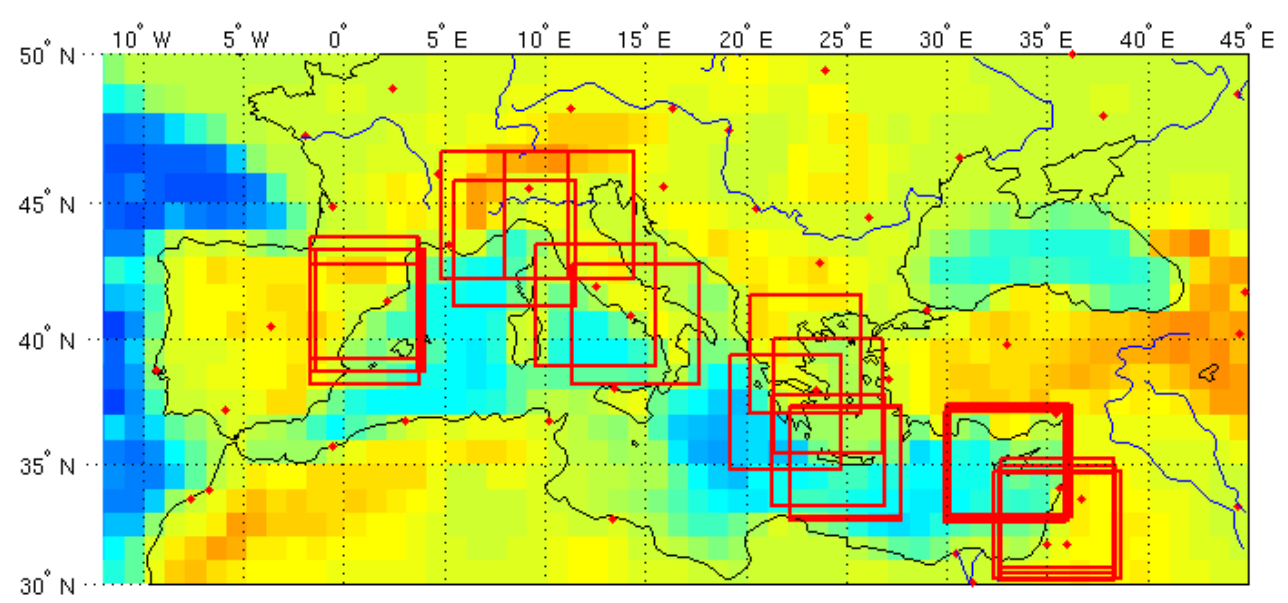

Fig. 3 - Map of the Mediterranean showing the boxes where intensive analysis was performed for 23 case studies.

\begin{tabular}{|c|c|c|c|c|}
\hline & Place & Date & $\begin{array}{c}\text { Central } \\
\text { Latitude N }\end{array}$ & $\begin{array}{c}\text { Central } \\
\text { Longitude W }\end{array}$ \\
\hline $\mathbf{1}$ & Israel & $01-02 / 04 / 2006$ & 32,5 & 35,5 \\
\hline $\mathbf{2}$ & Israel & $27-30 / 10 / 2006$ & 32,5 & 35,5 \\
\hline $\mathbf{3}$ & Israel & $04-06 / 12 / 2001$ & 33,0 & 35,5 \\
\hline $\mathbf{4}$ & Israel & $08-10 / 02 / 2006$ & 32,5 & 35,5 \\
\hline $\mathbf{5}$ & Israel & $24-25 / 12 / 2005$ & 32,5 & 35,5 \\
\hline $\mathbf{6}$ & Spain & $02 / 08 / 2005$ & 41,0 & 1,0 \\
\hline $\mathbf{7}$ & Spain & $11-13 / 10 / 2005$ & 41,0 & 1,0 \\
\hline $\mathbf{8}$ & Spain & $13-15 / 11 / 2005$ & 41,0 & 1,0 \\
\hline $\mathbf{9}$ & Spain & $12-14 / 09 / 2006$ & 41,0 & 1,0 \\
\hline $\mathbf{1 0}$ & Cyprus & $31 / 10 / 2005$ & 35,0 & 33,0 \\
\hline $\mathbf{1 1}$ & Cyprus & $06 / 11 / 2005$ & 35,0 & 33,0 \\
\hline $\mathbf{1 2}$ & Cyprus & $17-19 / 11 / 2005$ & 35,0 & 33,0 \\
\hline $\mathbf{1 3}$ & Cyprus & $17 / 12 / 2005$ & 35,0 & 33,0 \\
\hline $\mathbf{1 4}$ & Greece & $10-11 / 10 / 2006$ & 39,4 & 23,0 \\
\hline $\mathbf{1 5}$ & Greece & $12-13 / 10 / 2006$ & 35,6 & 24,1 \\
\hline $\mathbf{1 6}$ & Greece & $04-05 / 11 / 2004$ & 35,0 & 25,0 \\
\hline $\mathbf{1 7}$ & Greece & $23-25 / 11 / 2005$ & 37,1 & 22,0 \\
\hline $\mathbf{1 8}$ & Greece & $17 / 11 / 2005$ & 37,7 & 24,1 \\
\hline $\mathbf{1 9}$ & Roma, Italy & $15 / 06 / 2005$ & 41,2 & 12,5 \\
\hline $\mathbf{2 0}$ & Piemonte, Italy & $13 / 08 / 2006$ & 44,5 & 8,0 \\
\hline $\mathbf{2 1}$ & Emilia, Italy & $08 / 09 / 2006$ & 44,5 & 11,2 \\
\hline $\mathbf{2 2}$ & Bordighera, Italy & $14-15 / 09 / 2006$ & 43,5 & 8,5 \\
\hline $\mathbf{2 3}$ & Calabria, Italy & $13 / 08 / 2006$ & 40,5 & 14,5 \\
\hline & & & & \\
\hline
\end{tabular}

Table 1: List of flash flood events investigated in FLASH project.

All the remaining WPs of the project structured their research based on observations, simulations, and analysis of these events. The societal impacts, the lightning and 
rainfall observations, the model simulations, and the forecasts were all analyzed for the case studies to better understand how certain convective events develop into flash floods. In addition, new synoptic indicators were developed that may help future weather forecasters better predict the likelihood of flash floods.

As an example of the process of investigation during the FLASH project, a presentation of the analysis for one of the flash flood case studies will follow in more detail. This case from 12 to 15 September 2006 started with floods in northeastern Spain, and then moved to Italy producing additional flash floods and destruction. A maximum of $256 \mathrm{~mm}$ were recorded in Castelló d'Empuries (Catalonia, Spain), a quantity that corresponds to a return period of 100 years. However, more than 200 $\mathrm{mm}$ were recorded in $24 \mathrm{~h}$ with a maximum $5 \mathrm{~min}$ intensity of $249 \mathrm{~mm} / \mathrm{h}$ (Vilanova de Segrià , Catalonia, 14 September). The heavy rainfall produced flash floods due to the overflowing of a great number of short and ephemeral rivers, like the Muga river $(853.8 \mathrm{~km} 2)$, where the flow increased from 0 to $1000 \mathrm{~m} 3 / \mathrm{s}$ (gauge of Peralada). The heavy precipitation was produced by different Mesoscale Convective Systems, organized convective structures that remained stationary during some periods of time as a consequence of the different directions of cell propagation and MCS movement (Barnolas et al., 2008). This event resulted in huge damage in Barcelona (Fig. 4) which suffered from power and transportation failures. A tornado was observed, lightning damage and landslides were reported, and 90 cars were washed away. In addition, one person died as a result of the flooding. The CCS insurance company (Consorcio de Compensación de Seguros) paid out approximately s 56 million for damage produced by floods and landslides, and s 3.15

Million for damage produced by tornadoes. The additional analysis of this event in the individual WPs will be presented below. 


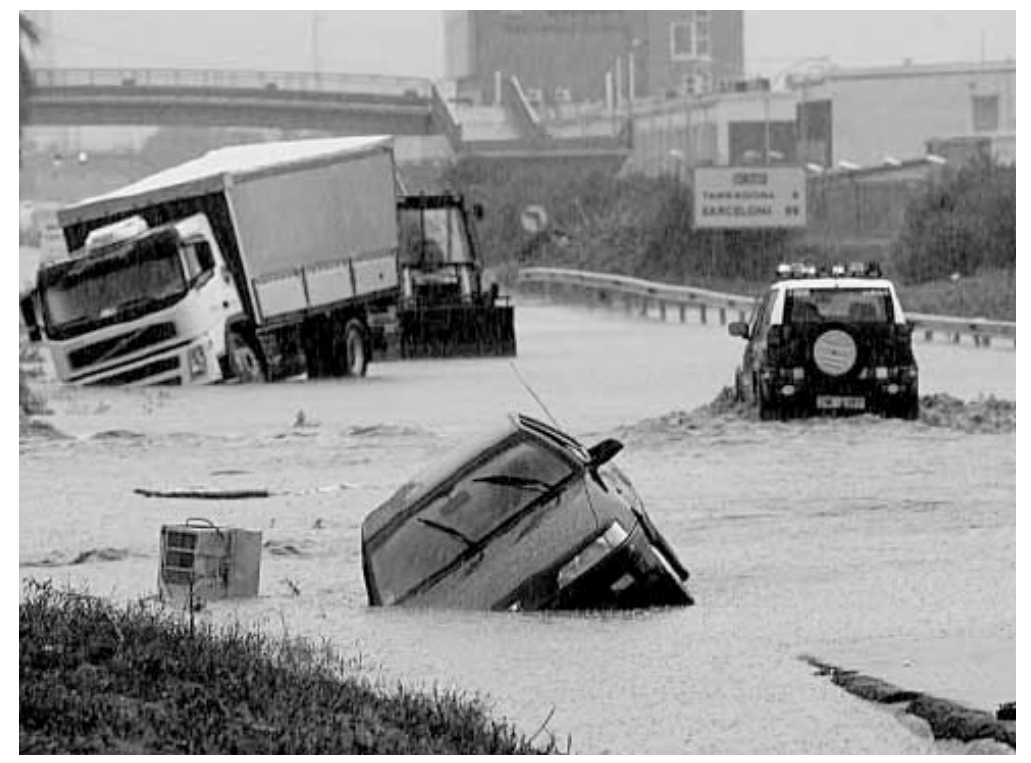

Fig. 4 - Highway flooding in Barcelona on 13 September 2006.

\section{Lightning data}

Lightning discharges emit electromagnetic radiation in the Very Low Frequency (VLF) range, propagating great distances from the thunderstorm source, by reflections off the ionosphere and the Earth's surface. Using exact GPS timing of the radio waves arriving at a set of VLF antennas (Fig. 5), it is possible to triangulate and to locate the lightning discharges in real time over large regions of the globe, with an accuracy of $5-10 \mathrm{~km}$.

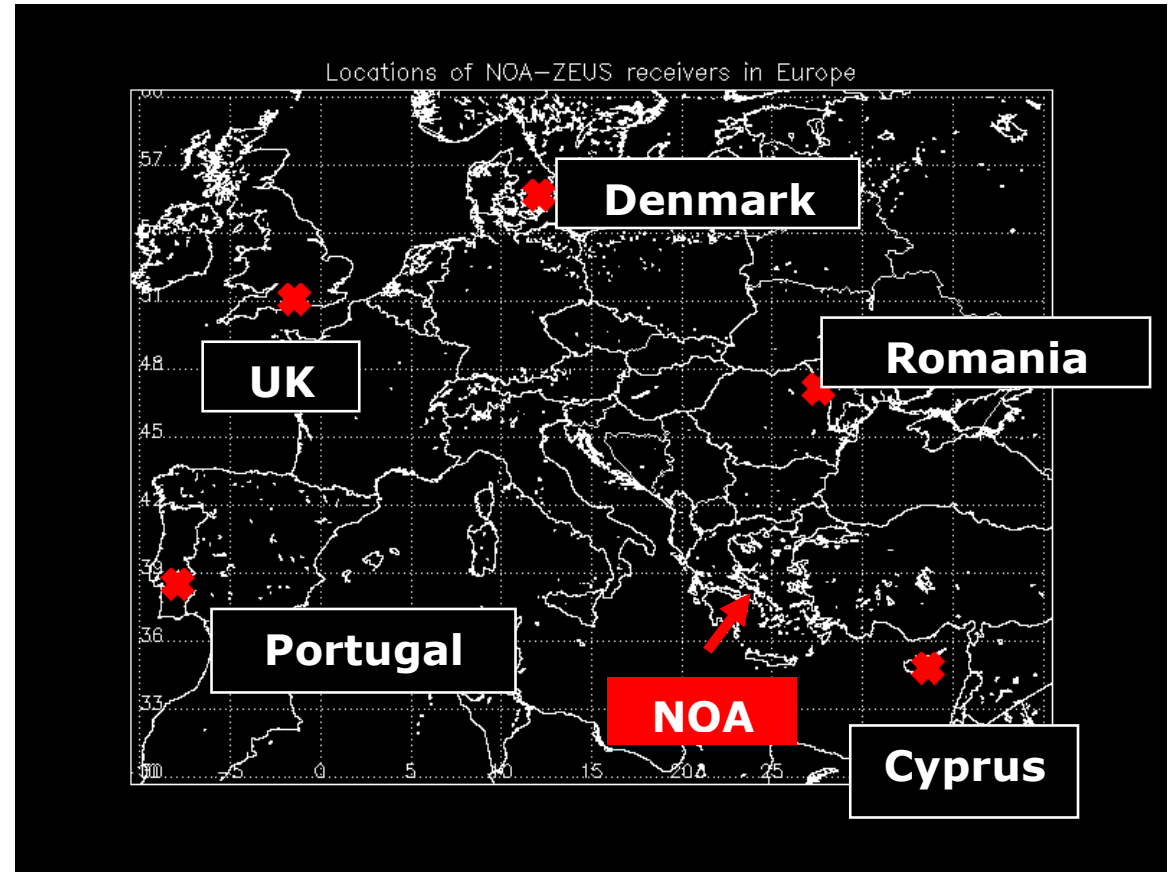

Fig. 5 - Location of VLF sensor used in the ZEUS network 
Such a network is run by the National Observatory of Athens (NOA), consisting of 6 VLF stations across Europe. The ZEUS network detects approximately $25 \%$ of all lightning flashes in Europe, recording the time and location of all detected flashes (Kotroni and Lagouvardos, 2008; Lagouvardos et al., 2009). While the network does not detect all lightning flashes, it does allow the real time detection and location of active thunderstorms across large areas of Europe and the Mediterranean. ZEUS data, in forms of maps updated every $15 \mathrm{~min}$, are provided operationally by NOA at its weather forecast webpage (http://www.noa.gr/forecast), as well as on the FLASH webpage (http://flashproject.org). In the latter webpage, ZEUS lightning data are displayed together with cloud-top infrared imagery from METEOSAT (also updated every $15 \mathrm{~min}$ ), so any interested individual or agency can have real-time access to vital information concerning the onset of convective activity over the Mediterranean and Southern Europe. The network is less sensitive to intracloud flashes, and weak cloud-to-ground discharges.

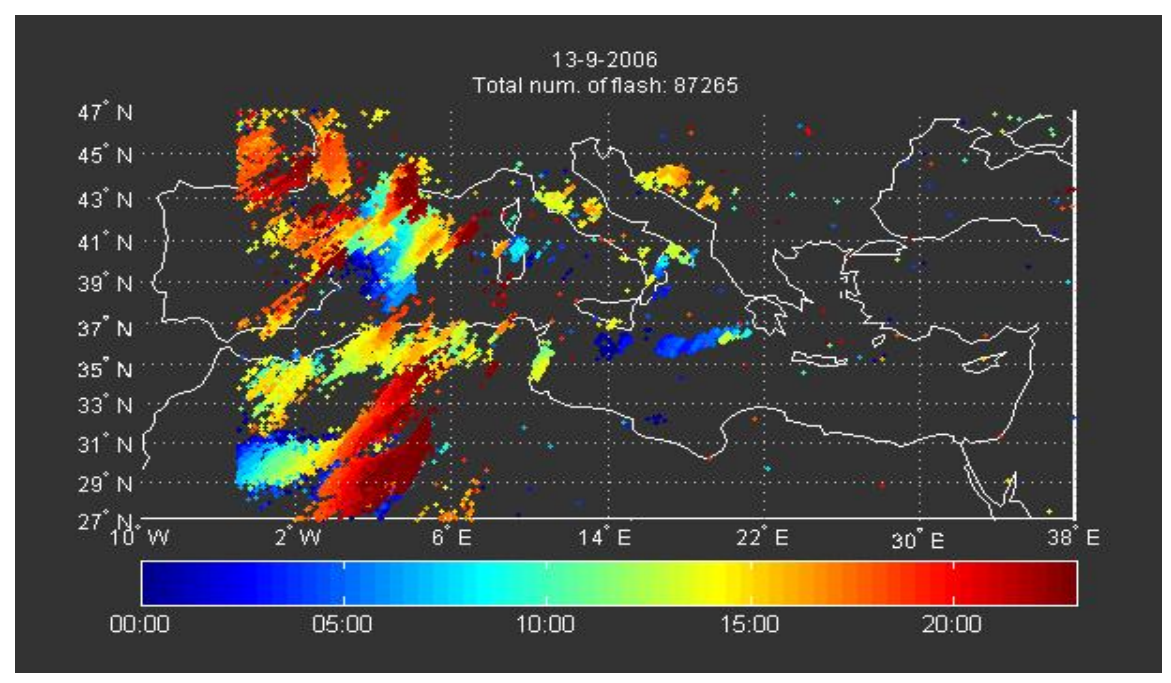

Fig. 6 - Spatial distribution of lightning flashes detected by ZEUS network on 13 September 2006, a day with flash floods in NE Spain.

In Fig. 6 is shown the detected lightning flashes on the 13 September 2006, the second day of the northeastern Spain flooding. The colour code represents the hour of the day when the lightning was detected, with the movement of the thunderstorm cells from the southwest to the northeast. More than 87,000 flashes were detected on this 
day across the Mediterranean. The cells propagated eastward toward Italy where flash floods were produced on the 14-15 September.

The lightning data were used in other WPs for comparison with rainfall data, model simulations, nowcasting, and data assimilation into weather forecast models.

\section{Microwave rainfall retrievals}

Space-borne passive instruments for rainfall and atmospheric observations may be divided into two groups, depending on the wavelength of the measured radiation from their sensors: i.e. visible-infrared (VIS-IR) and microwave (MW) sensors. VIS-IR sensors have the advantage of providing high-resolution measurements from very high altitudes. Thus, they are often placed aboard geo-stationary platforms allowing a continuous monitoring of (almost) a hemisphere. Visible to IR estimates of rainfall are only indirect because these VIS-IR measurements are sensitive only to the uppermost layer of clouds. They infer the underlying cloud structure from the top-ofthe-cloud appearance (from its brightness or from its temperature), based on the optical and thermal properties of the clouds. Microwave sensors, on the contrary, have the great advantage of providing a more direct measurement of the internal structure of the cloud, down to the freezing level. Microwave wavelengths are not affected by the high level cirrus clouds, and thus are more capable of penetrating the upper portions of the cloud and directly sensing the precipitating layers.

Two different satellite systems are available for precipitation observation from space: the meteorological geostationary satellites orbiting at $36,000 \mathrm{~km}$ altitude (similar to the telecommunication satellites), and the low level polar orbiting satellites (usually between 450 and $850 \mathrm{~km}$ altitude). Within the FLASH project, we have developed a new precipitation retrieval algorithm for observations from conically scanning MW radiometers (Sanò et al., submitted for publication), and have implemented the algorithm developed by Surussavadee and Staelin $(2008 \mathrm{a}, \mathrm{b})$ for cross-track scanning MW radiometers. Rainfall retrieval results for the case study above are shown in Fig. 7. In the left hand panels the brightness temperatures from the AMSU-B sensor channel $1(89 \mathrm{GHz})$ is presented. The right hand panels represent the rainfall retrievals 
in $\mathrm{mm} / \mathrm{hr}$. The top panels are for 02:16 UT, while the bottom panels are for 03:49 UT, separated by approximately $90 \mathrm{~min}$. The heavy rain over northeast Spain is clearly detected.
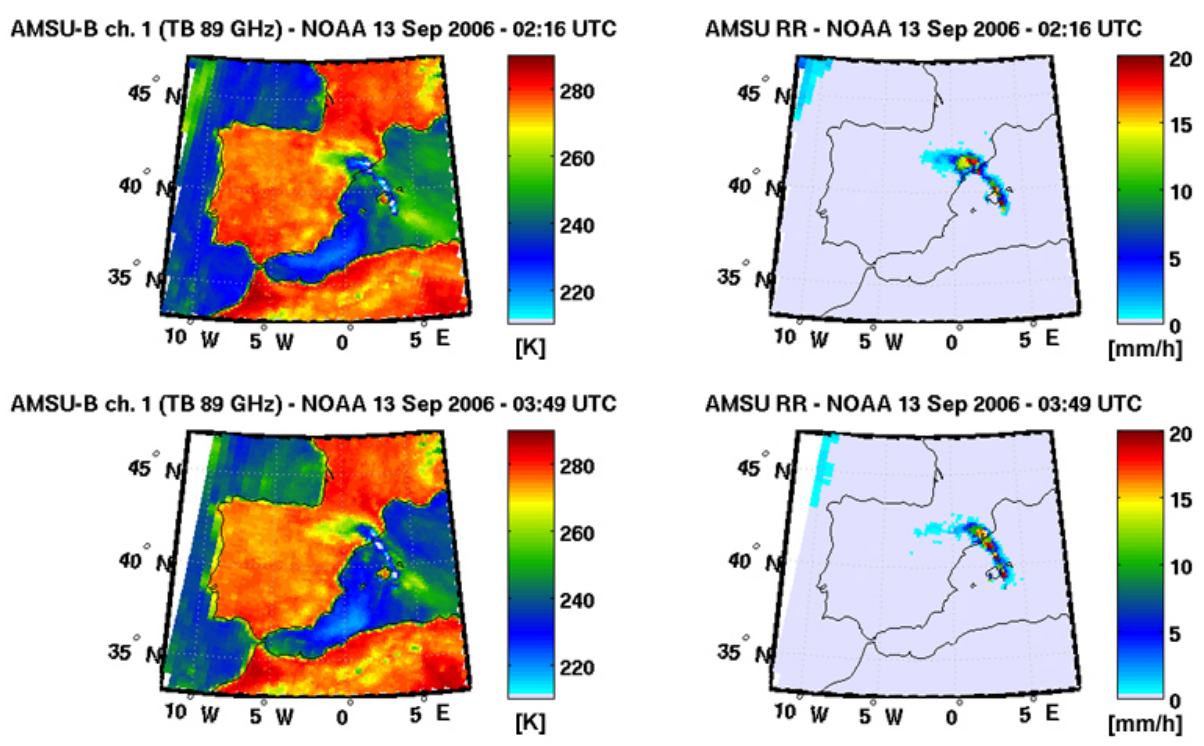

Fig. 7 - MW brightness temperature for 13 September 2006 02:16 UT (top left) and 03:49 UT (bottom left) together with the appropriate retrieved rainfall distributions (right panels).

However, a major disadvantage of using the polar orbiting MW sensors is the $90 \mathrm{~min}$ gap between local observations. In order to overcome this, the FLASH consortium developed a lightning-based "morphing" methodology for filling the gaps in rainfall data by combining the MW retrievals with the ZEUS lightning data. Specifically, we adopt the AMSU precipitation retrieval algorithm that was developed by Surussavadee and Staelin (2008a,b) at the Massachusetts Institute of Technology (MIT). This algorithm uses quasi real-time data from operational cross-track scanning radiometers to estimate instantaneous rainfall fields at the low earth orbiting satellite location. Then, the Lightning-based Precipitation Evolving Technique (L-PET) (Dietrich et al., in press) makes use of lightning data to propagate forward in time the rainfall fields estimated from the last available AMSU observations from space, until a new MW observation becomes available. Analyzing the change of gridded lightning occurrences, the method tracks the movement of precipitating cells and, dynamically, modulates the rain rates associated with the real time lightning occurrence density. In correspondence with the AMSU overpass, lightning occurrences allow the recognition 
of 8-connected different structures, that are identified as separate objects. Analyzing the correlation between two consecutive lightning occurrence maps, the L-PET moves the objects, scrambles the position of pixels within each object, and modulates the rain coupled to each pixel by using the variation of the number of lightning flashes in each object. The procedure is reiterated until a new AMSU overpass provides a new reference to restart the algorithm.
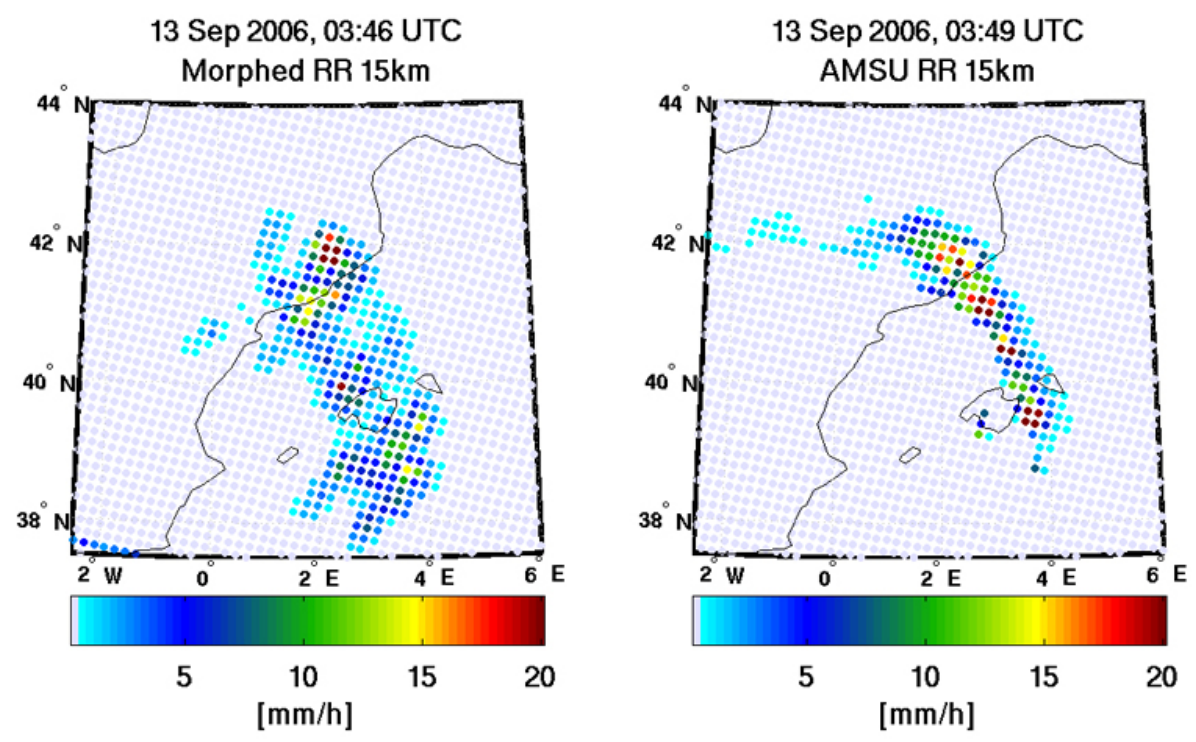

Fig. 8 - Morphed rainfall fields using lightning data for 03:46 UT, together with the retrieved rainfall fields at 03:46 UT using MW only.

As an example, at time t (e.g. 02:16 UT in Fig.7) the AMSU overpass provides rainfall estimates, and then the ZEUS lightning data every 15 min help to propagate the rain field. After $90 \mathrm{~min}$ of rainfall estimation using the L-PET (Fig. 8), a new satellite measurement is available (e.g. 03:49 UT in Fig.7) to update the relationship between the lightning and rainfall for the next 90 min. In Fig. 8 the 90 min morphed rainfall fields using ZEUS lightning data are compared with the MW rainfall retrieval at 03:49 UT. While differences do exist between the morphed rainfall fields, and the AMSU retrieved field, many similarities are noted, including the location and magnitude of the rainfall in the Barcelona area. It should also be noted that some of the spatial spreading of the morphed rainfall is due to temporary inaccuracies in the geolocation of lightning data, and not to the morphing algorithm. In similar way, other case studies have shown good performances of L-PET in following the evolution of convective storms (Dietrich et al., in press). However, a wider validation campaign is 
planned as soon as a similar propagation technique for stratiform precipitation regimes is developed based on infra-red data from geostationary satellites.

\section{Mesoscale meteorological modeling}

In addition to observational studies of the 23 flash flood cases, we also used different numerical models to simulate the meteorological conditions resulting in the various events. These models included the MM5 model (Version 3), a non- hydrostatic, primitive equation model using terrain-following coordinates (Dudhia, 1989). Several physical parameterization schemes are available in the model for the boundary layer, the radiative transfer, the microphysics and the cumulus convection. In order to select a combination of microphysical and convective parameterization schemes that better reproduce wet processes, Kotroni and Lagouvardos (2001) performed a comparison of various combinations of schemes for cases with important precipitation amounts over the E. Mediterranean. This comparison showed that the combination of the KainFritsch (Kain and Fritsch, 1993) parameterization scheme with the highly efficient and simplified microphysical scheme proposed by Schultz (1995) provides the most skilful forecasts of accumulate precipitation for a grid spacing of $24 \mathrm{~km}$. For that reason, for the simulations performed in the frame of the FLASH project, a combination of these two schemes has been used. In Fig. 9 a comparison between the observed rain gauge rainfall accumulation for $24 \mathrm{~h}$ for the 13 September 2006, and the simulated values using the MM5 model is presented (note that only results from the innermost grid of $2 \mathrm{~km}$ resolution are shown). The model slightly underestimates the peak rainfall values, but nevertheless it reproduces rainfall amounts reaching $200 \mathrm{~mm}$ at some stations for this day.

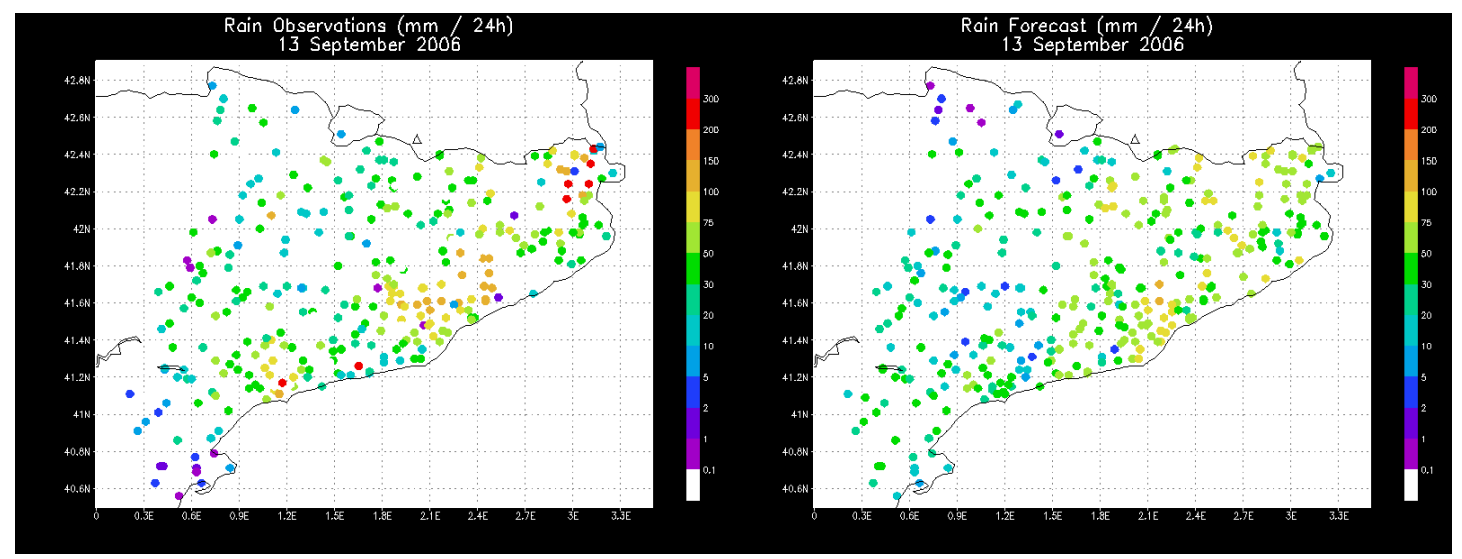


Fig. 9 - Observed (left) and simulated (right) rainfall at the raingauge network across Catalonia, Spain, on 13 September 2006.

In addition to the MM5 model, the Weather Research and Forecasting model (WRF) was also used to simulate the case studies. An important achievement of the project was the development of a Lightning Potential Index (LPI) based on the microphysical cloud parameters calculated by the WRF model (Yair et al., 2009; Lynn and Yair, 2010). This index relies on the fact that charge separation in clouds, leading to the generation of strong electric fields and eventually lightning activity, occurs through the interaction of graupel and ice particles in the presence of super-cooled liquid water. The LPI uses the amounts of ice, hail, and graupel within the mixed phase regions of model clouds, together with the model updraft velocities, to calculate the potential for electrical activity in the clouds. The LPI shows good agreement with the time and location of maximum lightning activity, and can be a valuable tool for forecasting regions where such activity is to be expected. It can be easily implemented in other medium range forecast models.

\section{Hydrological modeling}

The FLASH consortium had three hydrology groups working on local hydrological simulations in watersheds related to the case studies presented above.

The RIBS (Real-time Interactive Basin Simulator) model is a topography-based, rainfall-runoff model which can be used for real-time flood forecasting in midsize and large basins. Model use is especially attractive in connection with meteorological radar and distributed rainfall forecasting methods. The RIBS model is largely based on the detailed topographical information provided by Digital Elevation Models (DEM). Basin representation adopts the rectangular grid of the DEM, and input data, state variables and other soil properties such as the reduction of saturated hydraulic conductivity in depth; the residual soil-moisture content or minimum value of moisture under which the humidity cannot be extracted by capillary forces; the saturated moisture content; and the index of soil porosity, are also represented as data layers using the same scheme. The basic objective is to map the topographicallydriven evolution of saturated areas as the storm progresses, giving the spatial distribution of the infiltration capacity of the basin and representing the evolution of 
the saturated surface to the size of each cell. Two modes of runoff generation are simulated: infiltration excess runoff and return flow. Runoff generation depends on local soil moisture conditions. Moisture gets distributed along the soil column according to the dynamics of kinematic unsaturated flow. The soil column may be in one of three states: fully unsaturated, fully saturated or saturated at lower depths and unsaturated at the surface. The model captures the main features of runoff generation processes in watersheds while keeping computational efficiency for real-time use (Fig. 10) (Garrote and Bras, 1995a,b).

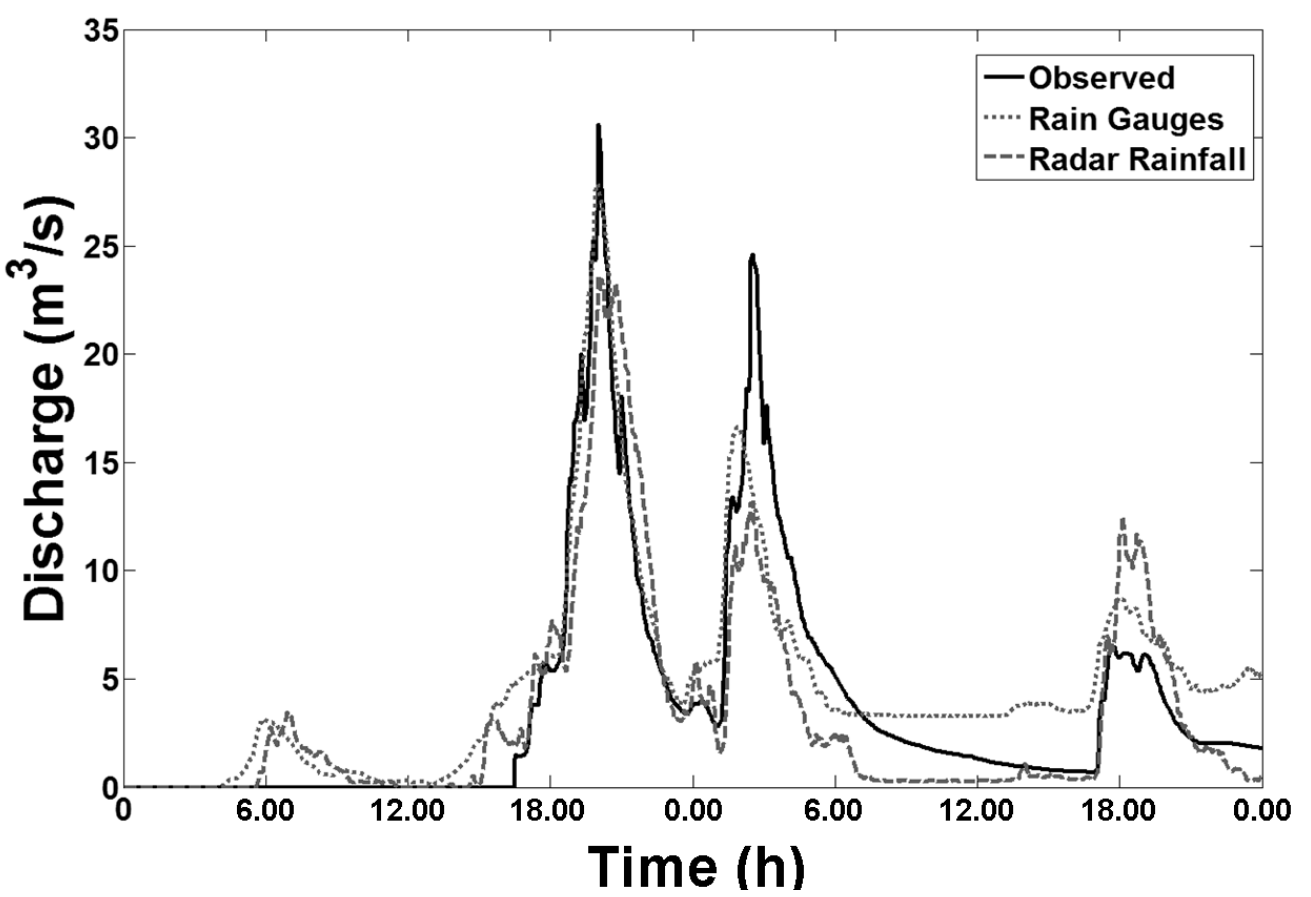

Fig. 10 - Barcelona flood event of 12-14 September 2006 in the Mogoda gauge station. RIBS simulation with precipitation from rain gauges is compared to simulation with radar rainfall.

The RIBS model was calibrated in two basins, the Besòs basin in Spain and the Harod basin in Israel (Mediero et al., in press). A sensitivity analysis was carried out over the time resolution of precipitation. A time resolution of $15 \mathrm{~min}$ was found to provide the best results, as this is the minimum to characterise the runoff processes and the maximum to characterise the rainfall variability in time (Atencia et al., 2010). 
The modeling approach of HYDROGEIOS is based on a network-type schematisation of the natural and the engineered components of the hydro-system (Efstratiadis et al., 2008). The two networks are linked through water diversions, abstractions and disposals. HYDROGEIOS represents the interactions between surface flows, ground water flows and engineered interventions, via a semi-distributed configuration striving to balance parsimony and physics fidelity. Multiple schematisation and parameterisation levels are adopted, by combining multiple levels of geographical data. Most components have a geo-reference and are handled via a GIS module that is also used for processing data and for generating derivative layers.

The CASURU hydrological model uses the SCS curve number rainfall-runoff model that is widely used in many studies over the world combined with the Kinematic wave routing model (Rozalis et al., 2010). This model minimizes the need for calibration, with the parameters of the SCS model being a function of soil type and land-use, derived from published tables. The parameters of the routing model are derived from topography data (Digital Elevation Model - DEM) and published tables.

\section{Nowcasting}

Nowcasting implies the short term (up to $3 \mathrm{~h}$ ) forecasting of heavy rainfall events. Using the ZEUS ground-based lightning detection network and the Warning Decision Support System- Integrated Information (WDSS-II) software, a nowcasting ability over the Mediterranean region was developed (Kohn et al., in press). Thousands of thunderstorms were used in developing the final nowcasting algorithm. Nowcasts are provided for 30, 60, 90 and 120 min lead time. Statistical verification was performed by calculating the hit, miss and false alarm rates, as well as the probability of detection (POD), false alarm rate (FAR) and the critical score index (CSI) scores in order to quantify the success of the now-casting.

The results show that the algorithm is overall successful in nowcasting the location of the lightning clusters; especially when applied to strong and consistent lightning events (it is these events which also have the strongest connection to flash floods). The POD values range between 0.46 for $30 \mathrm{~min}$ nowcasts and 0.25 for $120 \mathrm{~min}$ nowcasts. The CSI values are quite similar, but slightly lower. The nowcasting has a 
low false alarm rate, 0.03 for $30 \mathrm{~min}$ nowcasts, which is also beneficial for operational use. An example of the methodology for the Barcelona flash flood is presented in Fig.11. The algorithm first clusters the lightning flashes into thunderstorm cells. Every $15 \mathrm{~min}$ these clusters are recalculated and motion vectors estimated for each thunderstorm cluster. The storms are then propagated forward in time with updates to the motion vectors every $15 \mathrm{~min}$

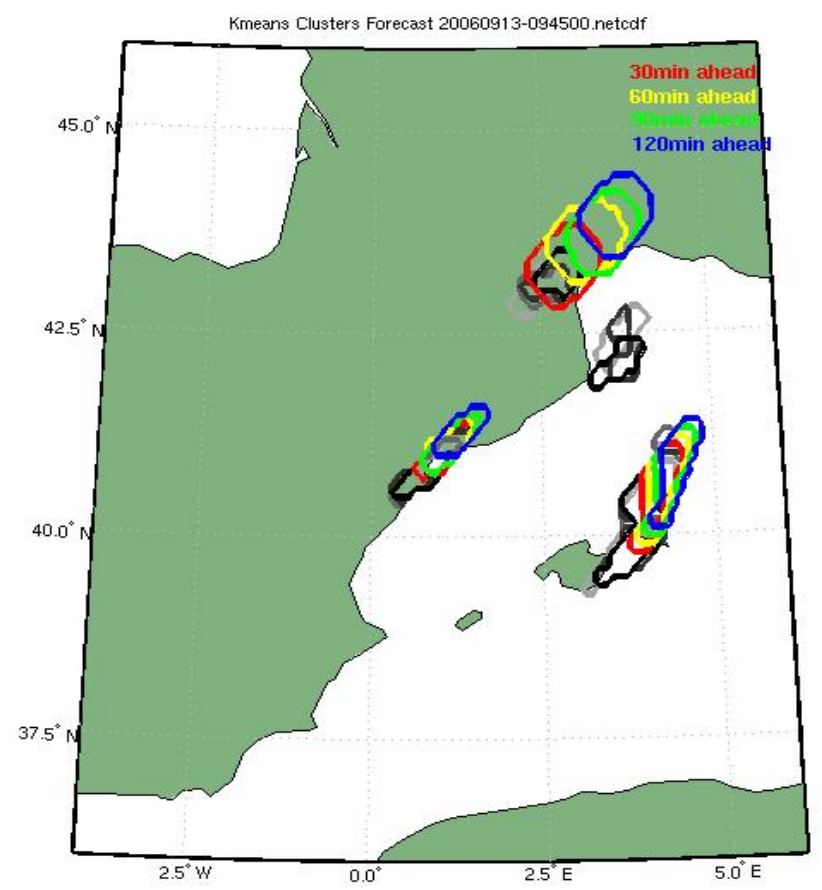

Fig. 11 - The nowcasting algorithm output for the 13 September 2006, initialized at 09:45 UT. The black and grey contours are the thunderstorm clusters at 09:30 UT and 09:45UT. The coloured contours represent the predicted regions of thunderstorm activity in $30 \mathrm{~min}$ (red), $60 \mathrm{~min}$ (yellow), $90 \mathrm{~min}$ (green) and $120 \mathrm{~min}$ (blue).

This method has been implemented for the use in real time nowcasting and is used to automatically seek and track areas of thunderstorm risk according to lightning intensity. The experimental nowcasts appear on the project website (www.flashproject.org/) .

\section{Forecasting}

While nowcasting involves the coming few hours, forecasting involves estimating the regions of heavy rainfall in the coming days. As part of FLASH, real-time forecasts of heavy convective rain over Europe were also provided. These forecasts are produced 
by the MM model, covering the major part of Europe and the Mediterranean basin. The corresponding maps are updated daily on the FLASH website (Fig. 12). Blue shading in the maps delineate areas where total precipitation within $6 \mathrm{~h}$ will exceed 10 $\mathrm{mm}$, and the bold red line areas where the convective part of the precipitation field will exceed the same amount.
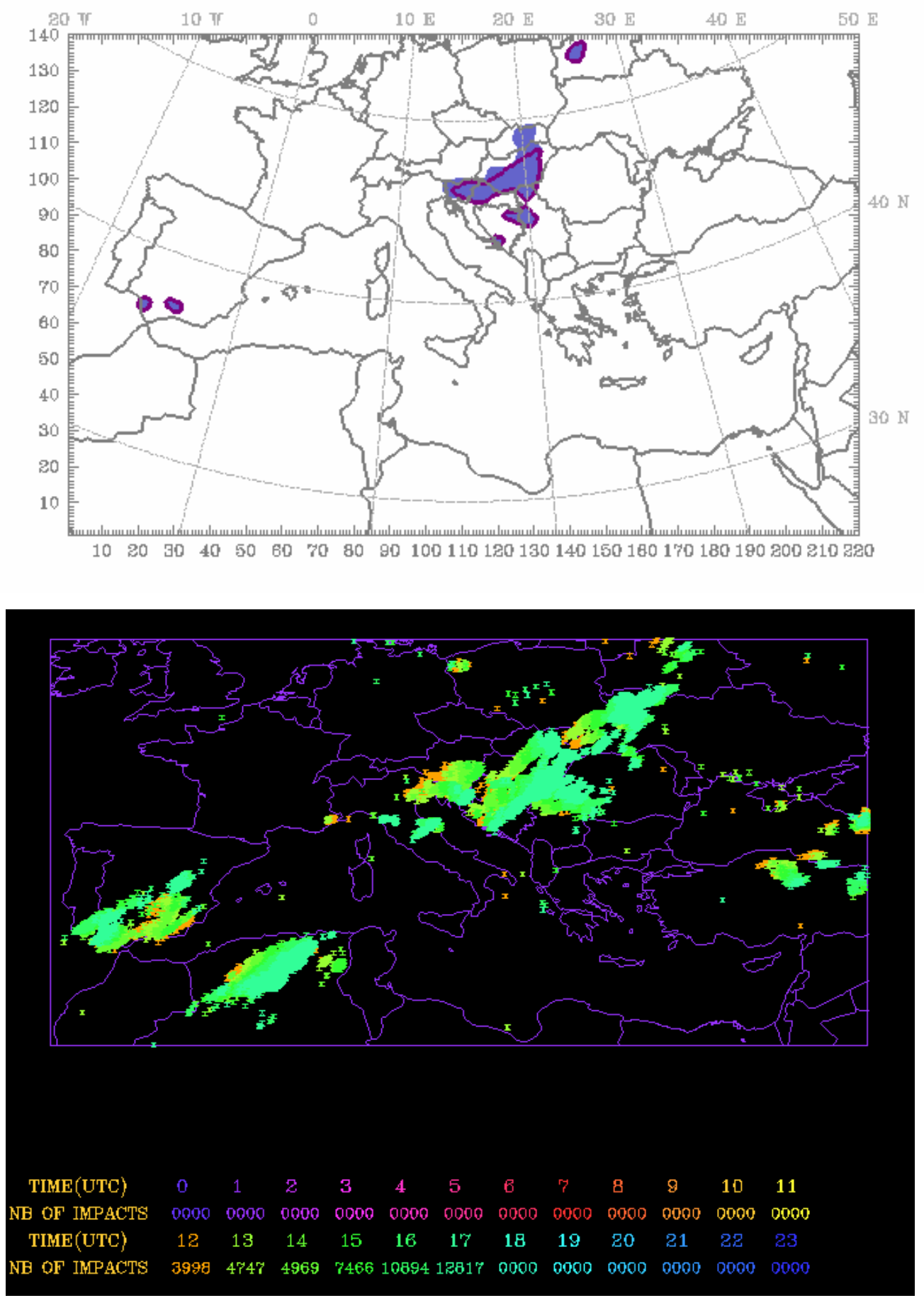
Fig. 12 - MM5 forecasts of 6-h accumulated precipitation valid at 1800 UTC, 14 July $2008(t+36$ to $t+42)$. Blue shading delineates the area where the forecasted total precipitation within 6 hours exceeds $10 \mathrm{~mm}$, while the red bold line delineates the area where the convective part of precipitation exceeds $10 \mathrm{~mm}$

The example in Fig.12 shows the forecast of a heavy rainfall event on 14 July 2008. The MM5 simulation is from 0000 UTC 13 July 2008, nearly 2 days before the event. For the same time periods of the forecast, ZEUS lightning data are plotted in Fig.12 (bottom). Inspection of these figures shows a good agreement between the dense lightning flashes in the areas where MM5 forecast heavy convective rain.
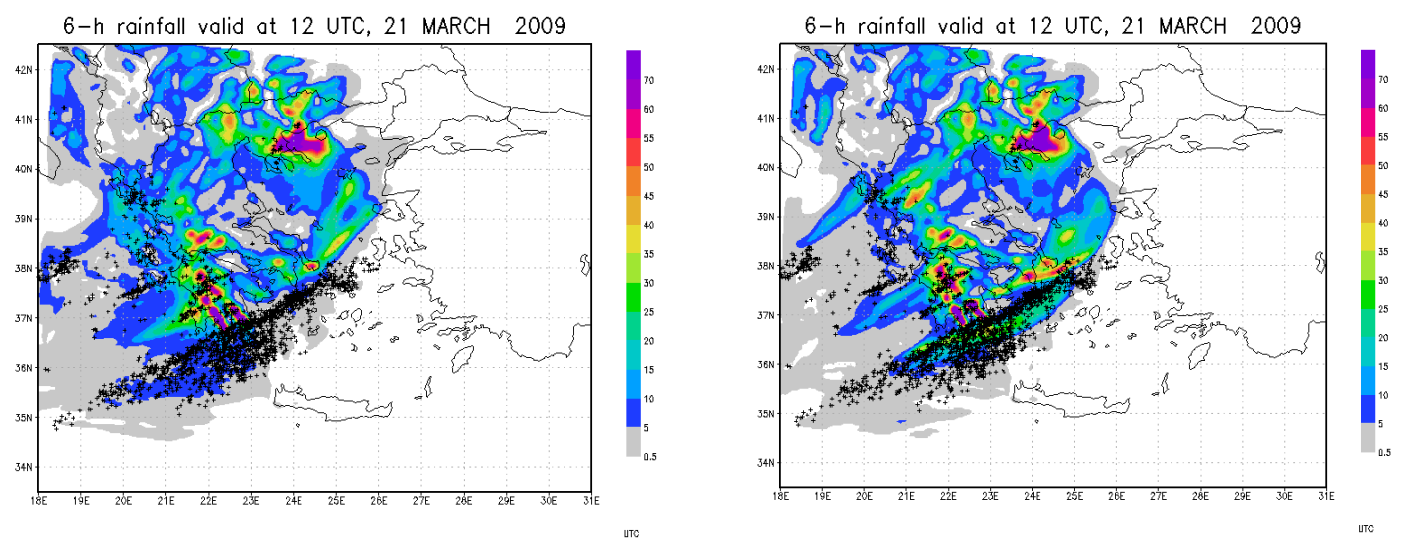

Fig. 13 - 6-h accumulated precipitation forecast at 18 UTC, 21 March 2009 (colours) and lightning observed during the same period (black dots) when using the control model run (left) and the model with assimilated lightning information (right).

During the project, the possibility of assimilating lightning data into numerical models, with the aim to improve the quantitative precipitation forecasts in the Mediterranean was explored. There have been numerous attempts to use lightning observations to improve weather forecast (Alexander et al., 1999; Pessi and Businger, 2009; Papadopoulos et al., 2005; Mansell et al., 2007). In the FLASH project the ZEUS data were used to improve the initial conditions of the MM5 forecasts, based on the method of Mansell et al. (2007). A qualitative improvement of the distribution of the precipitation field was found. In Fig. 13 the $6 \mathrm{~h}$ accumulated precipitation at 18 UTC, 21 March 2009, is presented along with the lightning observed during the same period, once simulated with no lightning assimilation (control) and once with the assimilation of data. It is evident that the assimilation simulation is able to reproduce a band of 
precipitation colocated with the band of observed lightning that was not found in the control run.

Another tool used for forecasting weather conditions that may result in flash floods, and often used by weather forecasters, is the synoptic analysis of pressure, and temperature fields. As part of the FLASH project new synoptic indicators (the modified K-index (MKI) and a dynamic rain index (DRI)) that are specific for the Mediterranean region were developed (Harats et al., 2010). The MKI is

$$
\mathrm{MKI}=\left(T_{500}-T_{850}\right) \times R H_{850700}+T d_{850}-\left(T_{700}-T d_{700}\right)
$$

where $\mathrm{T}$ and $\mathrm{Td}$ are temperature and dew point, respectively, while the subscripts denote the corresponding pressure level, and RH850,700 is the relative humidity average over the 850 and $700 \mathrm{~h} \mathrm{~Pa}$ pressure levels. The MKI is similar to the KI (Geer, 1996), except for the instability factor, T500 - T850, which is multiplied by RH850,700 in order to represent properly the sensitivity of the convective clouds to the ambient moisture availability. The DRI is the vertically integrated upward moisture flux throughout the troposphere, i.e.

$$
\mathrm{DRI}=\int_{925}^{300} \omega q d p
$$

where $\mathrm{p}$ is pressure, $\mathrm{v}$ is vertical velocity $(\mathrm{dp} / \mathrm{dt})$ and $\mathrm{q}$ is specific humidity. These new synoptic indices give a much better representation of the potential risk of flash floods in the Mediterranean, as can be seen in Fig. 14 for the case of the September 2006 flash flood in northeastern Spain. The maximum values of these new indices are fairly localized and centered over the flash flood region.
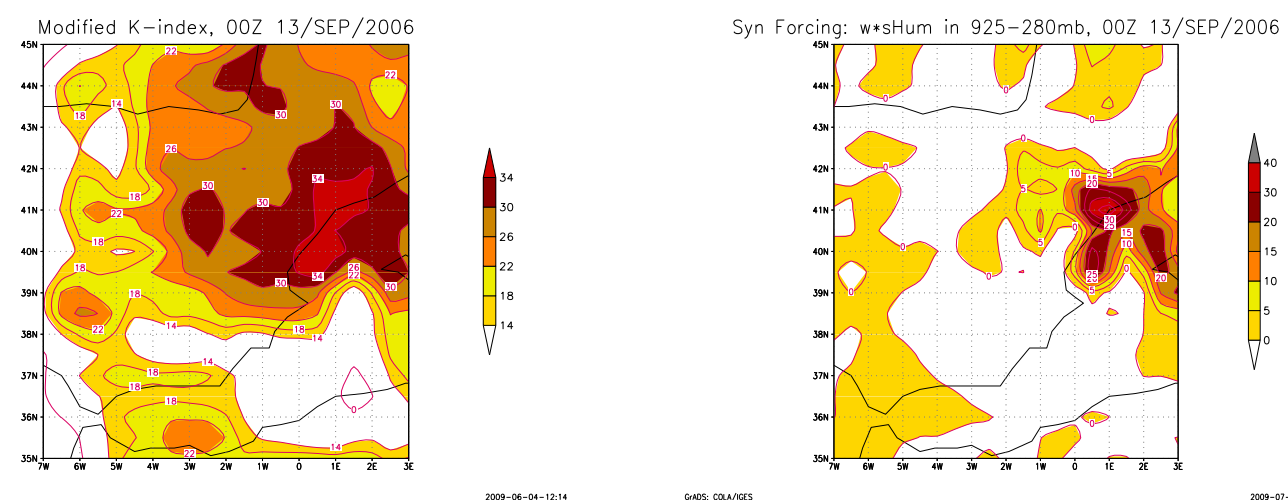
Fig. 14 - Modified K-Index (MKI) (left) and Dynamic Rain Index (DRI) for the 13 September $20060000 \mathrm{UT}$, based on synoptic data at 0.5 degree spatial resolution from the ECMWF reanalysis.

\section{Societal Impact and Educational Outreach}

A major focus in FLASH was studying the social impact, perception and communication of hydrometeorological hazards to the public and end users, as well as to address the strategy of FLASH in flood preparedness and mitigation. In order to accomplish this, different actions have been taken.

In the framework of the analysis of social impacts and climate change, a systematic database of news items related to natural hazards and climate change since 1982 was constructed using some of the most prestigious Spanish newspapers $(14,000$ news articles). This database, made using ACCESS, contains all the information about the news articles (number of pages, pictures, headlines, data about damages as well as technical data, and so on). This database was then used in the analysis of societal impact, risk perception and risk evolution. In this sense, the analysis of the evolution of the number of news items (1982-2007) shows a clear increasing trend. This may be due to various factors, such as a higher vulnerability and/or frequency, a lower tolerance threshold of society with respect to risks, and a major diffusion of news (Llasat et al., 2009a). A positive trend has also been observed in the specific case of floods and flash floods that cannot be associated to heavy rainfall increases, but, on the contrary, to a major vulnerability due to the occupation of flood prone areas, the increasing mobility and the poor risk knowledge (Llasat et al., 2009b, 2010b; Barrera et al., 2006). In addition, a database including more than 200 floods recorded in the Mediterranean Region between 1990 and 2006 and their damages has been constructed, introduced into a GIS platform, and analyzed, paying special attention in the 23 selected FLASH cases (Llasat et al., 2010a). Although this database does not show a generalized trend in the frequency of catastrophic floods recorded in this region, some positive trends in the impacts and frequency of extraordinary floods in the coastal regions have been found. These facts corroborate the decision of the UNISDR of classifying floods as a socio-natural risk (http://www.unisdr.org/eng/terminology/terminology-2009-eng.html) and the compulsory necessity of considering changes in flood characteristics not only in the 
climate change framework, but also considering all the aspects involved in the flood risk.

In the framework of the educational outreach of the FLASH project numerous learning tools were developed in order to educate the public about flash floods and thunderstorms, while providing information to be used by end users and stakeholders. Besides the project website (http://flashproject.org) hosting real time news stories of flash floods and thunderstorms from around the world, and real-time maps of lightning and cloud cover, a separate website focused on educational outreach and risk reduction, titled "LEARNING ABOUT FLASH FLOODS", (http://gama.am.ub.es/flash) (Fig. 15) was also created. There is also a Spanish version of the website (http://gama.am.ub.es/edrinacas). The site includes sections with multimedia contents (short films/animations of lightning, photos), news and interviews with the media. In the section prevention there is an illustrated guide of "what to do or not to do in the event of lightning and storms". With the aim to create a more user-friendly educational website, we have provided diagrams of the various phenomena (rain, lightning...) and cartoons designed by a professional graphic designer, illustrating how to avoid risky weather situations. Our own, exclusive character for the project, Peter-flash, has been created.

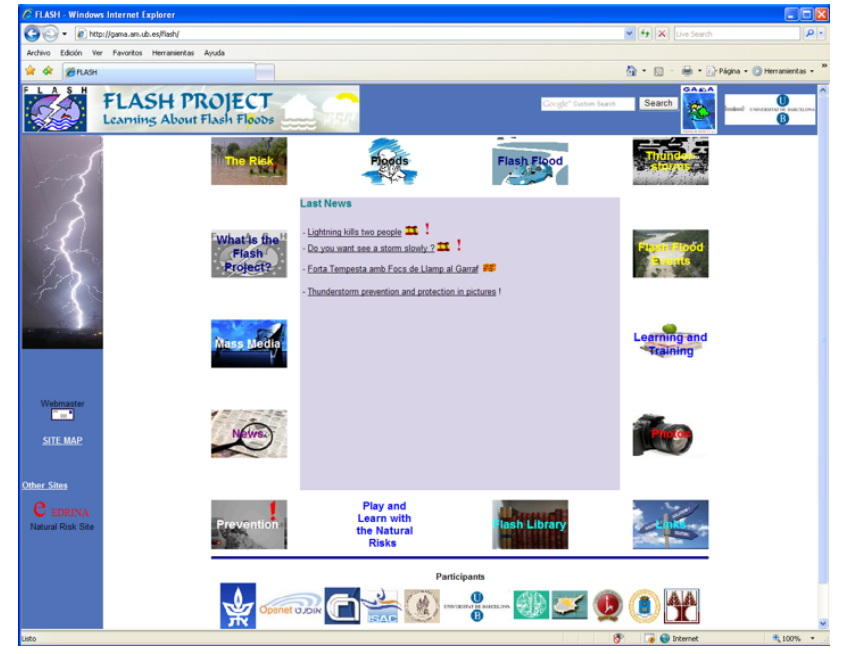

Fig. 15 - Image of the homepage of the FLASH educational website.

We have also developed 10 short video reports of 3-4 min about flash floods and lightning in Catalan, Spanish and English, to show the risk and how it is managed (chain alert), while communicating the science to the public with interviews with 
scientists and experts. An additional tool developed to increase the awareness of the population was an educational dossier including a compilation of pedagogic cards that can be used together or individually for educational purposes (school or university students and non-formal education). Finally, a dictionary of natural hazards (especially meteorological terms) with more than 300 words was created in collaboration with the Language Service of the University of Barcelona.

\section{Governance, science-policy interfacing and relationship with stakeholders.}

In order to share the results of the FLASH project and to receive feedback from stakeholders, an open session was held in Barcelona on 7 September 2009, in the framework of the 11 Plinius Conference of Mediterranean Storms, which was also sponsored by the FLASH project. Both events allowed the presentation of the main FLASH products and results.

Besides the scientific publications, The FLASH project has produced the following deliverables to stakeholders:

- $\quad$ An in deep report on the 23 case Studies

- A report about the floods recorded in the Mediterranean and societal impacts

- New lightning products for the Mediterranean region

- New nowcasting algorithms

- New nowcasting and forecasting products on-Line

- New educational outreach website and other products explained above

In addition, a direct collaboration with one of the end-users, the Meteorological Service of Catalonia, has been maintained and a new hydrometeorological tool will soon be operative. This tool has been developed in the framework of WP5, WP6 and WP7, because it combines MM5, radar and the hydrological model RIBS to improve not only the diagnosis of the flash flood events, but also the short forecasting using blending techniques (Atencia, 2011). With this approach it will be possible to extend the flash flood warning by $5 \mathrm{~h}$, a fact that is very important when the warning time is usually very short. 
The potential impact of these nowcasts and forecasts will have direct socio-economic impacts across the Mediterranean and Europe. Improved forecasts will be able to save lives, and perhaps reduce damage in some cases.

The EU Flood directive distinguishes three stages for dealing with flash floods: the preliminary flood risk assessment, the flood risk mapping and the flood risk management plans. In this sense, the FLASH project has worked in all three stages: WP1 and WP8 can improve the floods knowledge and the education of people prior to floods; the GIS map showing the flash flood distribution in the Mediterranean region and their impact can be used to improve flood risk mapping; and, finally, the lightning assimilation in models, and real time nowcasts/forecasts of heavy rainfall events are included in the improvement of warning. The added value of the lightning application in convective rainfall forecasts is that it can be used when there are no other data to rely on.

Another objective of the EU Flood directive is public participation in the planning process. This public engagement requires certain knowledge by the population, about floods. The FLASH project has addressed this aspect as well, mainly with the outreach products, the perception studies, and lectures in schools and to the public.

Finally, the results about trend analysis and climate change obtained in the context of FLASH project have been included in the second report of climate change in Catalonia (Llasat and Corominas, 2010) with a part devoted to proposals for policymakers.

\section{Summary and Conclusions}

The FLASH project was implemented for 3 years (plus an extension to a 4th year) and focused on the use of lightning observations in the study of flash floods across the Mediterranean region. Twenty three flash flood events were chosen for in-depth study, using atmospheric and hydrological data, model simulations, and analysis of the social and economic impacts of these events. It was found that real-time lightning 
observations on a regional basis are very useful in detecting, monitoring and tracking intense thunderstorm activity on large spatial scales. Lightning itself is a relatively easy parameter to measure and monitor using only a few monitoring stations, and the data can be used easily, in real time, with uniform availability across Europe and the Mediterranean.

In addition, it is shown that lightning data can significantly improve the estimation of rainfall from satellites. Lightning data add important information about convective clouds to the algorithms presently used for obtaining rainfall retrievals from space. Furthermore, since lightning is available continuously, it is very useful in "filling in the gaps" due to the coarse temporal sampling from low earth orbiting satellites. Lightning is also a very useful tool for providing short term nowcasts of intense convection across Europe. Since lightning data are available in close to real time, and cover large regions, lightning can be used to produce warnings for the public, local and regional governments about thunderstorm activity in the next few hours. It was also shown in the FLASH project that lightning data can be assimilated into weather prediction models to improve the initial conditions of the models, hence improving the 1-2 day forecasts of heavy precipitation and flash floods.

Unlike radars, lidars, satellites, and other expensive meteorological equipment, lightning networks can be built and expanded at relatively low cost, with low maintenance and running costs. Due to the benefit of lightning observations in improving FLASH rainfall estimates, severe weather warnings and forecasts, and generally reducing the risk of meteorological hazards to the European public, it is strongly recommended to use lightning data in weather centers around Europe and worldwide. We also encourage the future investment in regional/global lightning detection systems, both ground-based and from space.

\section{References}

Alexander, G. David, James A. Weinman, V. Mohan Karyampudi, William S. Olson, A. C. L. Lee (1999). The Effect of Assimilating Rain Rates Derived from Satellites and Lightning on Forecasts of the 1993 Superstorm. Mon. Wea.Rev., 127, 1433-1457.

Atencia, A., M.C. Llasat, L. Garrote and L. Mediero (2010). Effect of radar rainfall time resolution on the predictive capability of a distributed hydrologic model. Hydrology and Earth System Sciences Discussions, 7, 7995-8043. 
Atencia, A. (2011). Integration of meteorological models, hydrological and radar for floods forecasting in real time (in Spanish). Phd thesis, University of Barcelona, February 2011, 246 pp.

Barnolas, M., A. Atencia, M.C. Llasat and T. Rigo (2008). Characterization of a Mediterranean flash flood event using rain gauges, radar, GIS and lightning data. Advances in Geosciences, 17, 35-41.

Barrera, A., M.C. Llasat and M. Barriendos (2006). Estimation of the extreme flash flood evolution in Barcelona county from 1351 to 2005. Natural Hazards and Earth System Sciences, 6, 505-518

Defer, E., K. Lagouvardos and V. Kotroni. (2005). Lightning activity in the eastern Mediterranean region, J. Geophys. Res., 110, D24210, doi:10.1029/2004JD005710.

Dietrich, S., D. Casella, F. Di Paola, M. Formenton, A. Mugnai and P. Sanò (2010). Lightning-based propagation of convective rain fields. Nat.Hazards Earth Syst. Sci. (submitted).

Dudhia, J. (1989). Numerical study of convection observed during the winter monsoon experiment using a mesoscale two-dimensional model. J. Atmos. Sci., 46, 3077-3107.

Efstratiadis, A., I. Nalbantis, A. Koukouvinos, E. Rozos, and D. Koutsoyiannis (2008). HYDROGEIOS: A semi-distributed GIS-based hydrological model for modified river basins, Hydrology and Earth System Sciences, 12, 989-1006.

Garrote, L. \& Bras, R. L. (1995a) A distributed model for real-time forecasting using digital elevation models. J. Hydrol. 167, 279-306.

Garrote, L. \& Bras, R. L. (1995b) An integrated software environment for real-time use of a distributed hydrologic model. J. Hydrol. 167, 307-326.

Geer, I. W. (1996). Glossary of Weather and Climate, Am. Meteorol. Soc., 131..

Harats, N., B. Ziv, Y. Yair, V. Kotroni, and U. Dayan (2010). Lightning and rain dynamic indices as predictors for flash floods events in the Mediterranean, Adv. Geosci., 23, 5764, doi:10.5194/adgeo-23-57-2010.

Intergovernmental Panel on Climate Change (IPCC), (2007). Climate change 2007: the physical science basis. World Meteorological Organization (WMO) and UN Environment Programme (UNEP).

Kain, J. S., and J. M. Fritsch (1993). Convective parameterization for mesoscale models: The Kain-Fritsch scheme. The representation of cumulus convection in numerical models. $\mathrm{K}$. A. Emanuel and D. J. Raymond, Eds., Amer. Meteor. Soc., 246pp.

Kohn M., E. Galanti, C. Price, K. Lagouvardos and V. Kotroni (2010). Now-Casting Thunderstorms in the Mediterranean Region using Lightning Data. Atmos. Research (in press).

Kotroni, V., and K. Lagouvardos (2001), Precipitation forecast skill of different convective parameterization and microphysical schemes: Application for the cold season over Greece, Geophys. Res. Lett., 28(10), 1977-1980, doi:10.1029/2000GL012705.

Kotroni V amd K. Lagouvardos (2008). Lightning occurrence in relation with elevation, terrain slope and vegetation cover in the Mediterranean, J Geophys. Res, 113, D21118, doi:10.1029/2008JD010605

Lagouvardos K., V. Kotroni, H-D Betz and K. Schmidt (2009). A comparison of lightning data provided by ZEUS and LINET networks over Western Europe. NHESS, 9, 17131717.

Llasat, M.C., M. Llasat-Botija and L. López. (2009a). A press database on natural risks and its application in the study of floods in northeastern Spain, Natural Hazards Earth System Sciences, 9, 2049-2061.

Llasat, M.C., M. Llasat-Botija, M. Barnolas, L. López and V. Altava-Ortiz (2009b). An analysis of the evolution of hydrometeorological extremes in newspapers: the case of Catalonia, 1982-2006, Natural Hazards Earth System Sciences, 9, 1201-1212.

Llasat, M. C., M. Llasat-Botija, M.A. Prat, F. Porcú, C. Price, A. Mugnai, K. Lagouvardos, V. Kotroni, D. Katsanos, S. Michaelides, Y. Yair, K. Savvidou and K. Nicolaides (2010a). 
High-impact floods and flash floods in Mediterranean countries: the FLASH preliminary database, Advances in Geosciences, 23, 47-55.

Llasat, M.C., M. Llasat-Botija, A. Rodriguez and S. Lindbergh (2010b). Flash floods in Catalonia: a recurrent situation. Advances in Geosciences, 26, 105-111.

Llasat, M.C. and J. Corominas, 2010: Risks associated to Climate. In Llebot, J.E. (coord), (2010). Second Report on Climatic Change in Catalonia (in Catalan), IEC-CADS, Barcelona, Spain, 243-208.

Lynn, B. and Y. Yair (2010). Prediction of lightning flash density with the WRF model, $A d v$. Geosci., 23, 11-16, doi:10.5194/adgeo-23-11-2010

Mansell, E.R., C.L. Ziegler and D.R. MacGorman (2007). A lightning data assimilation technique for mesoscale forecast models, Mon. Wea. Rev., 135, 1732-1748.

Mediero, L, L. Garrote and F.J. Martín-Carrasco (2011). Probabilistic calibration of a distributed hydrologic model for flood forecasting. Hydrological Sciences Journal (In press)

Papadopoulos, T., G. Chronis, and E.N. Anagnostou (2005).Improving Convective Precipitation Forecasting Through Assimilation of Regional Lightning Measurements in a Mesoscale Model. Mon. Wea. Rev., 133, 1961-1977.

Pessi, A., and S. Businger (2009). The Impact of Lightning Data Assimilation on a Winter Storm Simulation over the North Pacific Ocean. Monthly Weather Review, 137, 31773195.

Rozalis, S., E. Morin,Y. Yair and C. Price (2010), Flash flood prediction using an uncalibrated hydrological model and radar rainfall data in a Mediterranean watershed under changing hydrological conditions, J. Hydrol., doi:10.1016/j.jhydrol.2010.03.021.

Sanò, P., D. Casella, A. Mugnai, G. Schiavon, E.A. Smith and G.J. Tripoli (2010). Bayesian estimation of precipitation from space-borne microwave radiometers using the Cloud Dynamics and Radiation Database (CDRD) approach: Description and application to case studies over Italy. IEEE Trans. Geosci. Remote Sens. (submitted).

Schultz, P. (1995). An explicit cloud physics parameterization for operational numerical weather prediction, Mon. Wea. Rev., 123, 3331-3317.

Surussavadee, C. and D.H. Staelin (2008a). Global millimeter-wave precipitation retrievals trained with a cloud-resolving numerical weather prediction model. Part I: Retrieval design. IEEE Trans. Geosci. Remote Sens., 46, 99-108.

Surussavadee, C. and D.H. Staelin (2008b). Global millimeter-wave precipitation retrievals trained with a cloud-resolving numerical weather prediction model. Part II: Performance evaluation. IEEE Trans. Geosci. Remote Sens., 46, 109-118.

Volland, H. (Ed.) (1995). Handbook of Atmospheric Electrodynamics. CRC Press, Boca Raton, Fl.

Yair, Y., B. Lynn, C. Price, V. Kotroni, K. Lagouvardos, E. Morin, A. Mugnai and M. C. Llasat (2009). Predicting lightning density in Mediterranean storms based on the WRF model dynamic and microphysical fields, s, J. Geophys. Res., 115, D04205, doi:10.1029/2008JD010868. 